\title{
A seasonality trigger for carbon injection at the Paleocene-Eocene Thermal Maximum
}

\author{
J. S. Eldrett ${ }^{1}$, D. R. Greenwood ${ }^{2}$, M. Polling ${ }^{3}$, H. Brinkhuis ${ }^{3}$, and A. Sluijs ${ }^{3}$ \\ ${ }^{1}$ Shell International Exploration and Production Inc. 3333 Highway 6, Houston, Texas 77082, USA \\ ${ }^{2}$ Biology Department, Brandon University, 270 18th Street, Brandon, Manitoba, R7A 6A9, Canada \\ ${ }^{3}$ Department of Earth Sciences, Faculty of Geosciences, Utrecht University, Laboratory of Palaeobotany and Palynology, \\ Budapestlaan 4, 3584 CD Utrecht, the Netherlands
}

Correspondence to: J. S. Eldrett (james.eldrett@shell.com)

Received: 23 September 2013 - Published in Clim. Past Discuss.: 22 October 2013

Revised: 4 February 2014 - Accepted: 25 February 2014 - Published: 16 April 2014

\begin{abstract}
The Paleocene-Eocene Thermal Maximum (PETM) represents a $\sim 170 \mathrm{kyr}$ episode of anomalous global warmth $\sim 56 \mathrm{Ma}$ ago. The PETM is associated with rapid and massive injections of ${ }^{13} \mathrm{C}$-depleted carbon into the ocean-atmosphere system reflected as a prominent negative carbon isotope excursion (CIE) in sedimentary components. Earth's surface and deep ocean waters warmed by $\sim 5^{\circ} \mathrm{C}$, of which part may have occurred prior to the CIE. However, few records document continental climatic trends and changes in seasonality have not been documented. Here we present the first high-resolution vegetation and paleoclimate reconstructions for the PETM, based on nearest living relative analysis of terrestrially derived spore and pollen assemblages preserved in an expanded section from the central North Sea. Our data indicate reductions in boreal conifers and an increase in mesothermal to megathermal taxa, reflecting a shift towards wetter and warmer climate. We also record an increase in summer temperatures, greater in magnitude than the rise in mean annual temperature changes, and a shift to a summer-wet seasonality. Within the CIE, vegetation varies significantly with initial increases in epiphytic and climbing ferns, and development of extensive wetlands, followed by abundance of Carya spp. indicative of broadleaf forest colonization. Critically, the change in vegetation we report occurs prior to the CIE, and is concomitant with anomalous marine ecological change, as represented by the occurrence of Apectodinium augustum. This suggests that amplifications of seasonal extremes triggered carbon injection.
\end{abstract}

\section{Introduction}

The Paleocene-Eocene Thermal Maximum (PETM) represents a $\sim 170 \mathrm{kyr}$ episode of anomalous global warmth $\sim 56 \mathrm{Ma}$ ago associated with a prominent negative carbon isotope excursion (CIE) in marine and terrestrial sediments. The source of the carbon injected during the PETM is still debated. Proposed hypotheses include (i) biogenic methane from gas hydrate dissociation (Dickens et al., 1995, 1997), (ii) $\mathrm{CO}_{2}$ from extensive oxidation of terrestrial organic carbon (Kurtz et al., 2003; Deconto et al., 2012), (iii) thermogenic methane derived from emplacement of a large igneous province (LIP) in the North Atlantic (Svensen et al., 2010) or combinations of such sources (Sluijs et al., 2007; Panchuk et al., 2008). At least four transient global warming events related to massive carbon input occurred through the late Paleocene-early Eocene, apparently paced by orbital cycles within the Milankovitch band (Lourens et al., 2005; Galeotti et al., 2010). Recent studies have therefore preferred mechanisms that require a climatological trigger for carbon injection, for example through enhancement of seasonal extremes that caused changes in ocean circulation, which in turn could dissociate submarine methane hydrates (Lunt et al., 2011). Critically, several records suggest that some of the warming preceded the injection of ${ }^{13} \mathrm{C}$-depleted carbon by several thousands of years, which may have triggered the injection of carbon (Sluijs et al., 2007; Secord et al., 2010; Kender et al., 2012). However, hitherto no data existed to evaluate if this warming included a seasonal bias. Such small time lags can only be resolved in stratigraphically

Published by Copernicus Publications on behalf of the European Geosciences Union. 


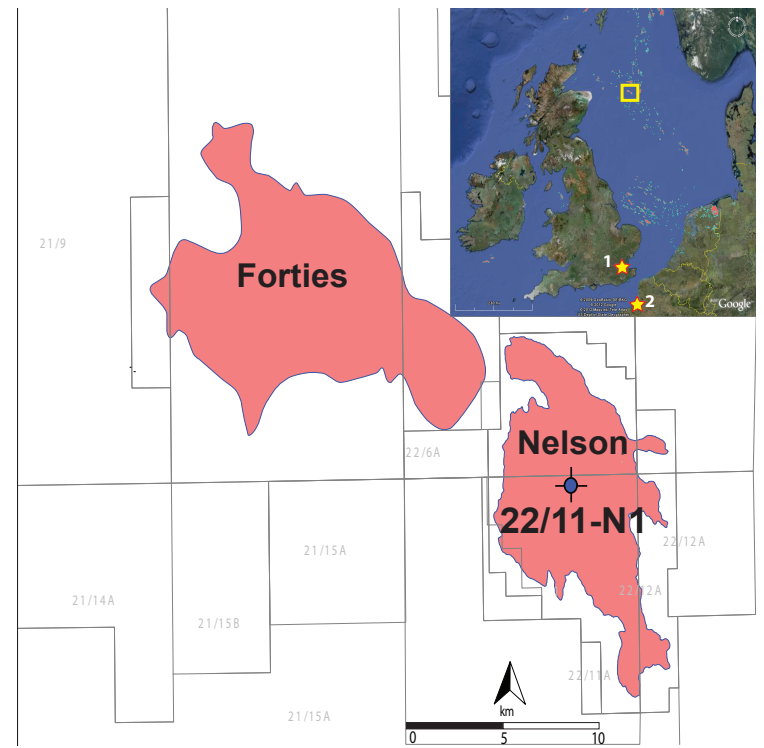

Fig. 1. Location map of 22/11-N1, Nelson Field, central North Sea (CNS). Colored polygons representing oil and gas fields. Red stars represent the location of recent studies on the (1) Cobham Lignite (Collinson et al., 2009) and (2) Vasterival section, NW France (Storme et al., 2012; Garel et al., 2013).

expanded sediment sections, typically from marginal marine areas because deep-marine sections are condensed due to the massive dissolution of carbonates (Zachos et al., 2005). The central North Sea basin yields vastly expanded PETM sections because of massive sediment supply from the hinterland (Sluijs et al., 2007). Numerous of such successions have been retrieved by oil exploration and production companies, but generally have not been made publicly available. We studied Shell Exploration and Production well 22/11-N1 $\left(57^{\circ} 39.46^{\prime} \mathrm{N}, 1^{\circ} 8.444^{\prime} \mathrm{E}\right.$; present water depth $\left.\sim 83 \mathrm{~m}\right)$ in the central North Sea (Fig. 1). This core was drilled in 1991 from the Nelson Field platform penetrating an expanded section comprising heterolithic sands and mudstones of the Forties fan system. Our objectives were to examine spores and pollen (sporomorphs) from palynological residues to understand vegetation dynamics during the PETM interval and then apply nearest living relative (NLR) analyses on these assemblages to reconstruct mean annual temperature (MAT) estimates, including seasonal estimates of cold and warm month mean temperature (CMMT, WMMT). We also generated mean annual precipitation (MAP), and for the first time we also provide estimates of cold and warm month mean precipitation (CMMP, WMMP), as measures of precipitation seasonality as shifts in the hydrological regime have been linked to the PETM (Schmitz and Pujalte, 2007; Sluijs et al., 2008).

\section{Materials and methods}

\subsection{Core 22/11-N1, Forties Sandstone Member}

The Forties Sandstone is dominated by an elongate NW-SEoriented depositional system, reflecting sediment-dominant sediment supplied by extensive deltaic feeders located to the north and west of the main depocenter (Bowman, 1998). The main source of sand and muds to the submarine fan is derived from the rejuvenated and recently uplifted Mesozoic hinterland (Bowman, 1998; White and Lovell, 1997; Håland et al., 2000; Underhill, 2001; Mudge and Jones, 2004; Maclennan and Jones, 2006). Quantitative paleoenvironmental reconstruction of this system requires that records of terrestrial spores and pollen recovered from these sediments accurately reflect the vegetation zones of the hinterland at the time of deposition. Therefore, an understanding of the primary factors controlling transport and sedimentation of pollen and spores is essential. Two main transportation mechanisms that account for the majority of spores and pollen in marine sediments are (i) atmospheric transport by wind and (ii) hydrodynamic transport by rivers and runoff. The majority of the cored sediments at well 22/11-N1 reflect heterolithic lowstand deposits, and are characterized by more continuous fluvial input of both sands and suspended muds as rivers and sediment bypass the shelf. Due to this relatively "short-time" recycling on the shelf, the sporomorphs are less likely than other deposits to be affected by sediment winnowing. There is potential for hydrodynamic sorting within the turbidity flow itself, although it is difficult to quantify. However, as the main sporomorph trends recorded in 22/11-N1 are identified regionally and in different depositional settings (shelf, slope and basin, fairway channel/margin) as per the Shell Exploration and Production PT Zonation (Schroder, 1992), the role of hydrodynamic sorting in the timescale presented here is likely to be limited.

Atmospheric transport by wind is mainly reflected by the abundance of Pinaceae counts, principally Pinus pollen, which is strongly over-represented in marine sediments due to significant long-distance dispersal, although counts $>50 \%$ likely reflect continental sources within $500 \mathrm{~km}$ (Hooghiemstra, 1998). Therefore, the abundances of the spore and pollen assemblages are expressed as percentages of the main sum, which includes all pollen except PinusPicea spp. Due to the over-representation of Pinus and Picea pollen in these sediments, these taxa were also excluded from the NLR analyses so that the climate estimates reflect secular changes on the adjacent landmass, rather than more effective wind dispersal and/or variations in elevation, and/or distance from the source regions.

\subsection{Isotope analyses}

In order to constrain the age model and identify the Paleocene-Eocene CIE, samples were analyzed for bulk 
organic carbon isotope on the total organic carbon fraction $\left(\delta^{13} \mathrm{C}_{\mathrm{TOC}}\right)$. An aliquot of each powdered sample was reacted with $\sim 50 \mathrm{ml}$ of $10 \% \mathrm{HCl}$ overnight to remove any carbonate present, the acid was decanted, and then the sample was rinsed 3-4 times with $250 \mathrm{ml}$ of deionized water. The samples were dried at $60^{\circ} \mathrm{C}$ in an oven and analyzed using a MAT253 mass spectrometer.

\subsection{Palynological analyses}

Samples from core 22/11-N1 were demineralized using cold hydrochloric $(30 \% \mathrm{HCl})$ and hydrofluoric $(60 \% \mathrm{HF})$ acids. Concentrated nitric acid $\left(70 \% \mathrm{HNO}_{3}\right)$ was then employed for oxidation purposes, followed by sieving through 10micron and 30-micron sieves to concentrate the remaining residues, which were then air-dried on coverslips and mounted on slides using Elvacite. Residues were analyzed using a stereo-binocular microscope until 300 specimens of marine palynomorphs, while the entire slide was counted for terrestrial palynomorphs.

\subsection{Quantitative climate reconstructions based on sporomorph assemblages}

We analyzed the spore-pollen (sporomorph) record of terrestrial vegetation as proxies of climate using two variants of nearest living relative (NLR) analysis: bioclimatic analysis and the mutual climate range (MCR) technique. The method of bioclimatic analysis is as described by Greenwood et al. (2005), and is comparable to coexistence analysis (Mosbrugger and Utescher, 1997) but differs from that method in how outliers are removed and in how the estimate is calculated. The MCR technique applies a comparable methodology to coexistence analysis, but uses a different set of modern plant climate range data sets, and has been rigorously tested for North American Quaternary and modern samples for both accuracy and precision (Thompson et al., 2012).

The first step in NLR analysis is to identify as many sporomorph taxa with nearest living relatives as possible from the fossil floras for which climate profiles are available or can be developed. The sporomorph taxa that were utilized in this study and their NLR analyses can be found in the Supplement. Grimm and Denk (2012) found that estimates of temperature for modern forest sites using a NLR approach based on regional modern plant climate range data sets (e.g., Thompson et al., 2012) were much more accurate than using the PALAEOFLORA database (Mosbrugger and Utescher, 1997) and recommended against using the latter database of NLR climate ranges. The climatic ranges ("profiles") of the NLR analyses used in this study are therefore mainly from the same sources as those used by Greenwood et al. (2005, 2010), Eldrett et al. (2009), Fang et al. (2011), Thompson et al. (2012) and Pross et al. (2012), consistent with the recommendations of Grimm and Denk (2012).
These sources included NLR climate data primarily obtained from Thompson et al. (2012), which include climate range data for the majority of genera and species of tree occurring in North America, as well as climate range data for taxa whose primary modern occurrence is in China (Fang et al., 2011). For taxa not represented in these databases, we obtained geographical distribution data from the Australian National Herbarium Specimen Information Register (2011), from the Natural Resources Canada (2012) online database, and/or the Global Biodiversity Information Facility (http://www.gbif.org/) and determined the climate profile for each taxon using the mathematical climate surface software ANUCLIM 6.1 (Hu and Hutchinson, 2013) for Australian and Canadian records, or using WorldCLIM (Hijmans et al., 2005, 2012) for NLR analyses distributed widely outside of these areas and not available from the other sources. Both ANUCLIM and WorldCLIM use the ANUSPLIN software package for generating climate data $(\mathrm{Xu}$ and Hutchinson 2013; Hijmans et al., 2005, 2012). The same method was used by Fang et al. (2011) to generate climate range data for their Chinese database. Each profile contains the maximum and minimum values for a range of climate and related environmental variables (Thompson et al., 2012; Fang et al., 2011). The estimate for each climate parameter from bioclimatic analysis is the mean value of the 10th and 90th percentile of the maximum and minimum values across all taxa recorded in a sample, with the total range between these plotted as an "error bar"(Greenwood et al., 2005; Eldrett et al., 2009; Pross et al., 2012). This statistical process objectively removes extreme outliers, consistent with recent recommendations (Grimm and Denk, 2012; Thompson et al., 2012). All samples used in our analysis had at least 11 NLR analyses with climate profiles $($ minimum $=13$, mean $=18.7$, maximum NLR $=26$ ), as per the recommendations of Thompson et al. (2012).

\section{Results and discussion}

The sediments in core 22/11-N1 are barren of calcareous and siliceous microfossils, but yield rich and abundant palynological assemblages, notably organic-walled dinoflagellate cysts (dinocysts; Fig. 2) and spores and pollen from higher plants (Fig. 3), suitable for paleoecological and paleoclimatological analyses. Along with palynological data, our $\delta^{13} \mathrm{C}_{\mathrm{TOC}}$ provides stratigraphic framework to constrain our paleoclimatological estimates for the PETM interval.

\subsection{Stratigraphic framework}

The recovery of diverse and abundant dinocyst, spore and pollen assemblages allows the regional biostratigraphic zonation (Schroder, 1992) to be applied to these sediments constraining the PETM interval (Fig. 2). In particular, the occurrence of the dinocyst Areoligera gippingensis in the 
a.

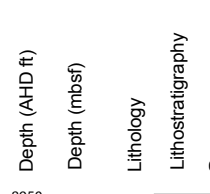

b.

c.

d.<smiles>C1CC2CCC1CC2</smiles>

e.

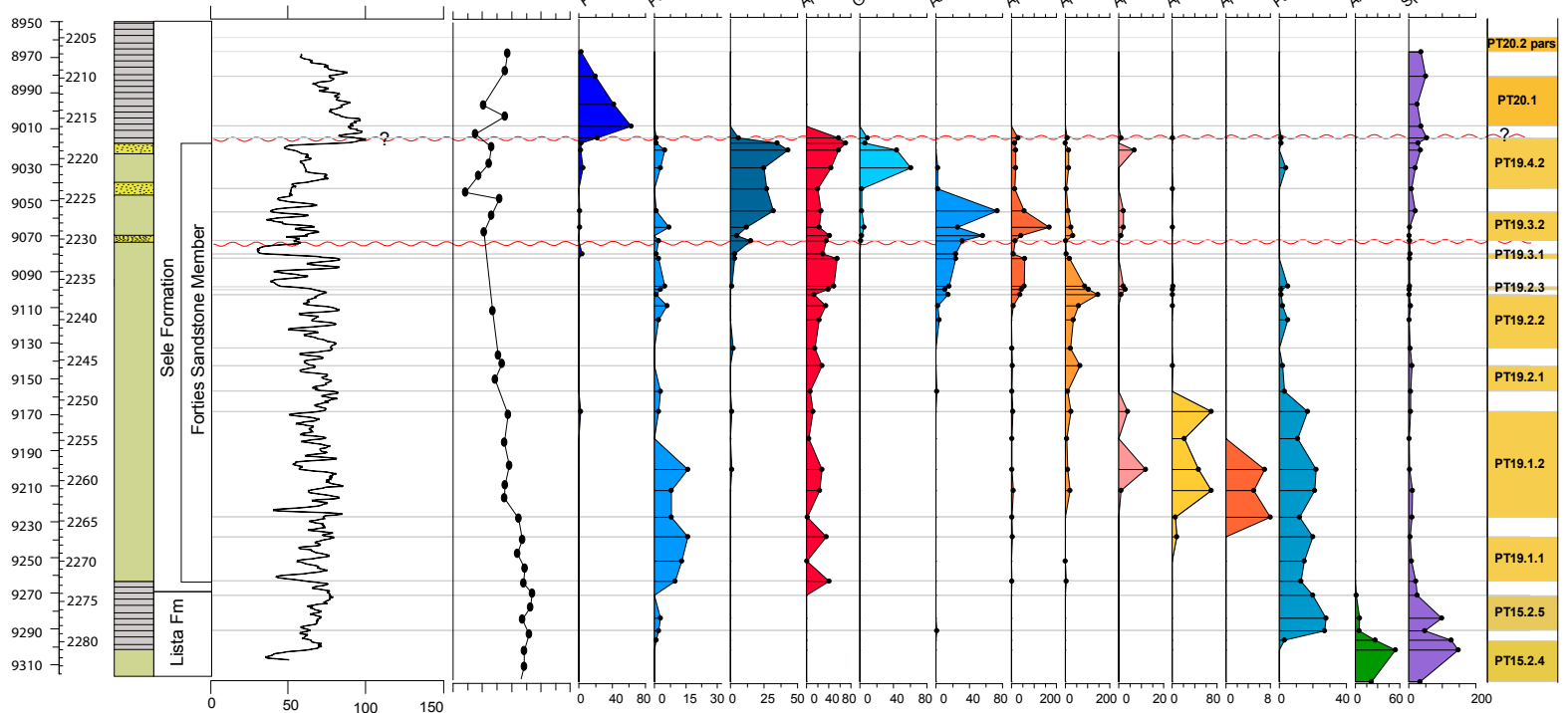

Fig. 2. Data from well 22/11-N1: (a) lithostratigraphy/lithology, (b) gamma-ray log, (c) carbon isotope data $\left(\delta^{13} \mathrm{C}_{\mathrm{TOC}}\right)$, (d) selected distribution (specimen counts) of regional dinocyst bioevents, and (e) applied regional biostratigraphic zonation after Schroder (1992).

Lista Formation marks the latest Paleocene, and abundant occurrence of the Apectodinium spp., and in particular Apectodinium augustum in core 22/11-N1 between $2272.1 \mathrm{mbsf}$ and $2218.07 \mathrm{mbsf}$ is diagnostic of the PETM (Bujak and Brinkhuis, 1998; Schmitz et al., 2004; Sluijs et al., 2007; Egger et al., 2009; Sluijs and Brinkhuis, 2009; Kender et al., 2012). The occurrence of A. augustum excludes the possibility that the CIE reflects one of the younger early Eocene transient global warming events (Lourens et al., 2005). However, it has been shown that occurrences of Apectodinium spp. and A. augustum can occur below the Paleocene-Eocene negative carbon isotope excursion (CIE; see Sluijs et al., 2007; Sluijs and Brinkhuis, 2009), which varies globally between -2 and $-7 \%$ o (see overview in McInerney and Wing, 2011). We note a slight negative isotope trend from $2273.8 \mathrm{~m}$, which could be interpreted as the initiation of the PaleoceneEocene CIE. However at this interval $\delta^{13} \mathrm{C}_{\mathrm{TOC}}$ values decrease by $<0.5 \%$ from background, and are not significant $(t$ test: $t$ stat $=0.04 ; t$ critical $=1.85 ; p$ value $=0.48 ; \alpha=$ $0.05)$. It is possible that the slight shift in $\delta^{13} \mathrm{C}_{\mathrm{TOC}}$ values at $2273.8 \mathrm{~m}$ reflects the changing contribution of organic matter (see Sluijs and Dickens, 2012) as this coincides with the influx of amorphous organic matter at the boundary between the underlying Lista Formation and the Forties Sandstone Member. Our $\delta^{13} \mathrm{C}_{\mathrm{TOC}}$ record from core 22/11-N1 indicates the Paleocene-Eocene CIE between 2264.5 and $2215.1 \mathrm{mbsf}$, with a negative shift of up to $3.8 \%$ (Fig. 2), followed by increasing values up to 2207.4 mbsf. A $t$ test confirms that this isotope excursion as defined from $2264 \mathrm{mbsf}$ is significant $\left(t\right.$ stat $=9.81 ; t$ critical $=1.7 ; p$ value $=4.6 \times 10^{-10}$; $\alpha=0.05)$. This suggests that in core 22/11-N1, A. augustum occurs immediately prior to the Paleocene-Eocene CIE.

The magnitude and shape of the CIE in well 22/11-N1 is also anomalous compared to typical deep marine records, which are usually characterized by an abrupt negative shift, often termed the "initiation", followed by a phase of relatively stable, low values, which has been termed the "body" of the CIE, and a subsequent "recovery" to higher $\delta^{13} \mathrm{C}$ values (McInerney and Wing, 2011). Our $\delta^{13} \mathrm{C}_{\mathrm{TOC}}$ record gradually declines by $\sim 1 \%$ o for the majority of the cored section, and shows a second decline of $\sim 3 \%$ o between 2224.4 and 2217.3 mbsf. This trend is more consistent with $\delta^{13} \mathrm{C}_{\mathrm{TOC}}$ records from shelf sections, such as on Spitsbergen, where Cui et al. (2011) interpret a smeared-out onset of the CIE as a 20000 -year injection time of ${ }^{13} \mathrm{C}$-depleted carbon at the onset of the PETM, rather than reflecting the mixing of Paleocene and Eocene organic carbon (Sluijs et al., 2012). This also seems to be the case in our record and the central North Sea in general, where the sediments were being shed from the rapidly uplifted Caledonian Highlands, bypassing the shelf and thus would have relatively short organic matter residence times. In theory it is possible to generate a negative CIE of about $4 \%$ during the early Paleogene due to changes in marine organic matter source (Sluijs and Dickens, 2012). However, our palynological data indicate no significant change in organic matter source through 


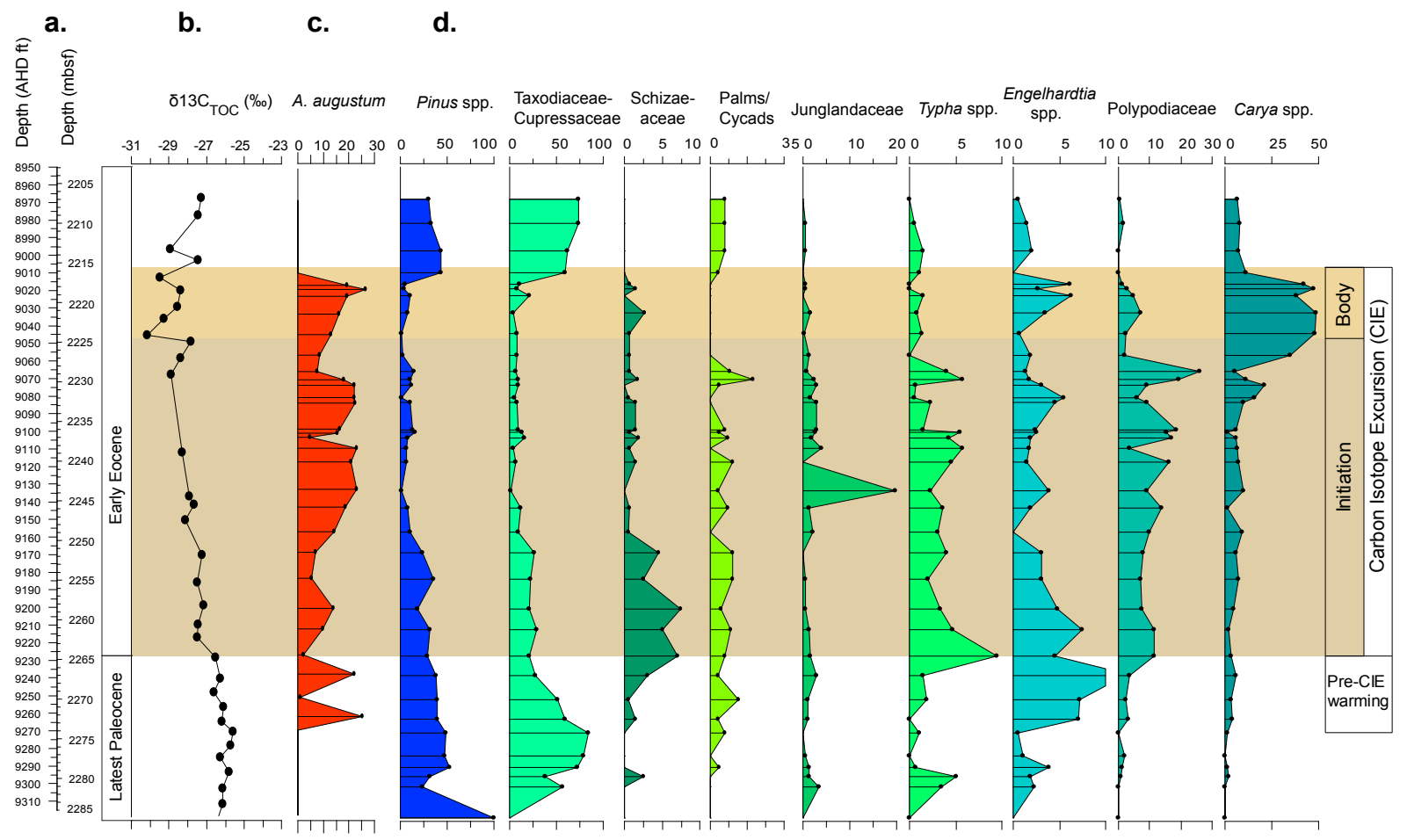

Fig. 3. Data from well 22/11-N1: (a) depth (AHD - along hole depth), (b) carbon isotope data $\left(\delta^{13} \mathrm{C}_{\mathrm{TOC}}\right)$, (c) distribution and percentage abundance of the dinocyst $A$. augustm, and (d) selected spore and pollen percentage abundance.

the PETM interval, being mostly comprised of amorphous organic matter, with subordinate equal proportions of marine and terrestrial palynomorphs. Our observations are consistent with maceral-specific $\delta^{13} \mathrm{C}$ record from a nearby core in the central North Sea (Kender et al., 2012) and with specific biomarker $\delta^{13} \mathrm{C}$ record from a marginal marine section in Denmark (Schoon et al., 2013). In either case, the effect of differing organic matter source would be to dampen the magnitude of the CIE but not extend its apparent onset (Cui et al., 2011). Therefore, we interpret our carbon isotope record, with minimum $\delta^{13} \mathrm{C}_{\mathrm{TOC}}$ values being reached only $\sim 40 \mathrm{~m}$ above the onset of the CIE, as reflecting a $20 \mathrm{ka}$ injection time of ${ }^{13} \mathrm{C}$-depleted carbon at the onset of the PETM and indicative of a massively expanded CIE. This would require relatively high sedimentation rates $\left(2.5 \mathrm{~m}-5 \mathrm{~m} \mathrm{kyr}^{-1}\right)$, something that is fully supported in similar depositional environments today, such the Brazos-Trinity submarine fan system with sedimentation rates as high as $60 \mathrm{~m} \mathrm{kyr}^{-1}$ (Primez et al., 2012) and the Amazon fan, with sedimentation rates up to $10 \mathrm{~m} \mathrm{kyr}^{-1}$ (Piper and Deptuck, 1997). While the initiation of the CIE seems complete, our stratigraphic interpretation indicates an erosive surface at the base coarse sand unit ( $2225.2 \mathrm{mbsf}$ ), so that part of the "CIE body" is missing from the record (Fig. 2). Furthermore, the "CIE recovery" phase in these sediments is relatively condensed, though it could be partly eroded, resulting in an incomplete record for this latter interval.

\subsection{Palynofloral assemblages}

The terrestrial palynomorphs in well 22/11-N1 (Fig. 3) were mostly transported to the basin via submarine fans. However, the main trends are regionally defined, occurring both in shelf and pelagic sediments, and thus reflect regional climate events. Uppermost Paleocene sediments (2264.5-2285.1 mbsf) yield palynofloral assemblages dominated by the microthermal to mesothermal Pinaceae Abies (fir), Picea (spruce) and Pinus. Mesothermal conifers such as Taxodiaceae-Cupressaceae (e.g., Taxodium and/or Metasequoia) are also abundant, while dicots such as Alnus (alder), Carya (hickory), and Juglans (walnut) are consistently present. These taxa indicate the presence of a moderately diverse mixed conifer-broadleaf vegetation. Towards the PETM, a significant increase ( $t$ test: $t$ stat $=4.5$; $t$ critical $=1.7 ; p$ value $=0.0002 ; \alpha=0.05)$ in mesothermal to megathermal taxa occurs including palms/cycads, Engelhardia (walnut family, Juglandaceae), and Icacinaceae (e.g., Compositopollenites rhizophorus, meso-megathermic vines of the extant genus Iodes; Song et al., 2004). The occurrence of palms/cycads indicates coldest month mean temperatures (CMMTs) $>5^{\circ} \mathrm{C}$ in the modern (Greenwood and Wing, 1995). However, when grown under the high- $\mathrm{CO}_{2}$ conditions that prevailed during the Eocene (Lowenstein and Demicco, 2006; Smith et al., 2010), palms are even less resilient to seasonal cooling, suggesting that CMMTs were $>8^{\circ} \mathrm{C}$ (Royer 


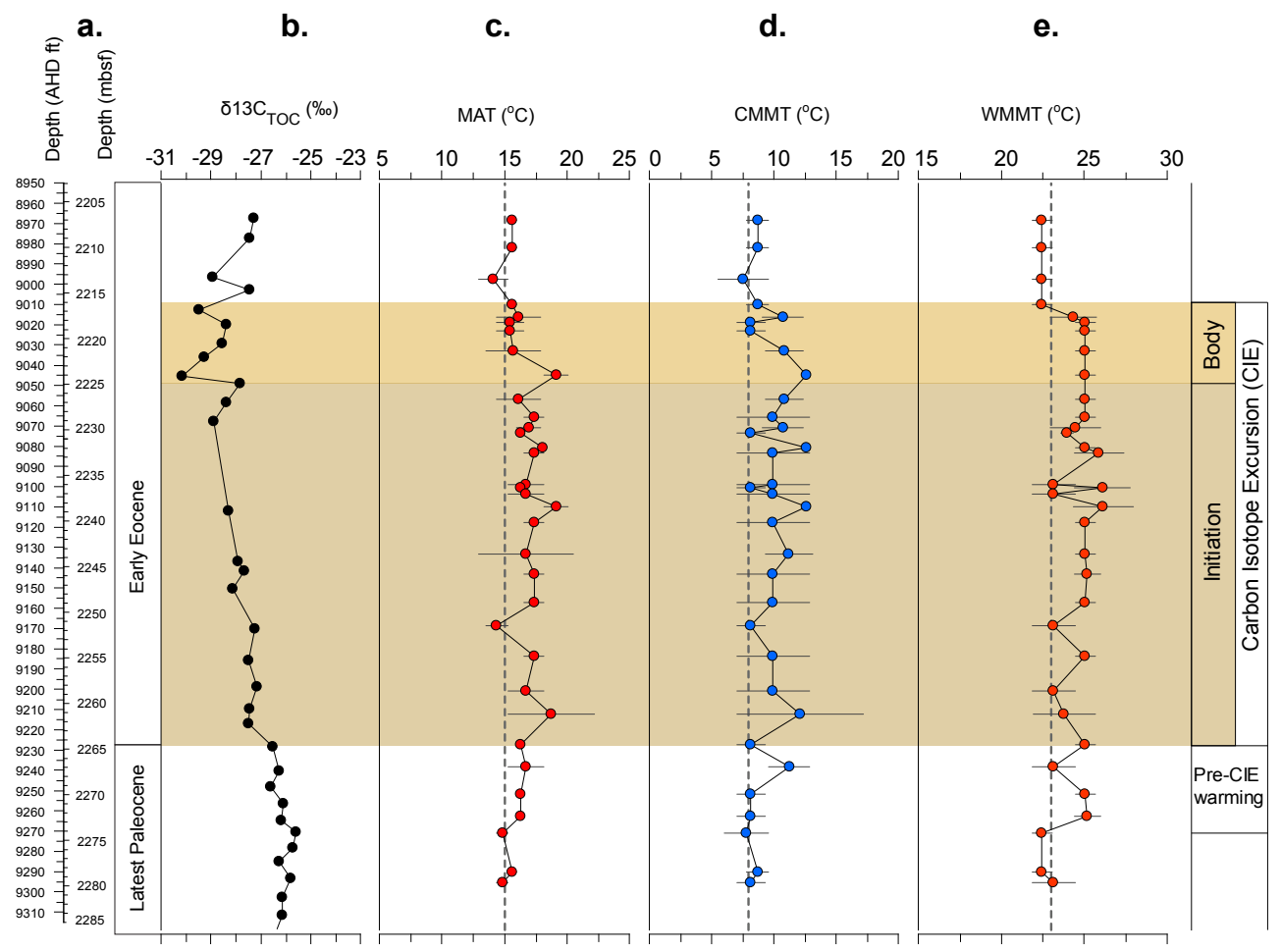

Fig. 4. Record of Paleocene-Eocene temperature data from well 22/11-N1: (a) depth and age, (b) carbon isotope data $\left(\delta^{13} \mathrm{C}_{\mathrm{TOC}}\right)$, (c) MAT, (d) CMMT, and (e) WMMT. (c-e) Horizontal bars and shaded area represent the minimum and maximum estimate returned from the method.

et al., 2002). Hence, the first occurrence of palms/cycads at $2278.1 \mathrm{mbsf}$ combined with increasing abundances of other megathermal taxa implies a shift to warmer climates.

The initiation of the CIE is characterized by a significant increase $(t$ test: $t$ stat $=6.7 ; t$ critical $=1.7 ; p$ value $\left.=9.3 \times 10^{-8} ; \alpha=0.05\right)$ in ferns, namely Schizaeaceae (cf. Anemia and/or Lygodium, climbing fern) and Polypodiaceae (epiphytes), while palms/cycads, Engelhardia, and Icacinaceae are still represented. An abundance of ferns is generally associated with tropical to warm temperate wet climates, with the diversification of epiphytic ferns in the latest Paleocene-Eocene being associated with extreme warmth and the expansion of the topical forest biome to more mid-high latitudes (Schuttpelz and Pryer, 2009; Harding et al., 2011). Within the CIE initiation interval, Typha spp./Sparganiaceae become a significant $(t$ test: $t$ stat $=$ $2.3 ; t$ critical $=2.1 ; p$ value $=0.03 ; \alpha=0.05$ ) component of the palynofloral assemblages, indicating an increase in the wetland component, represented by the development of rush/reed marshes in the coastal regions. This is consistent with the development of extensive wetlands in the North Sea region, and also the eastern US gulf coast during the CIE interval (Harrington, 2008).

The interval between 2225 and 2215 mbsf shows greater variability in the $\delta^{13} \mathrm{C}_{\mathrm{TOC}}$ signal, and is dominated by Carya spp., indicative of broadleaf forests and woodland communities. Palms/cycads are not present in this interval, which may support this interpretation. At $\sim 2217 \mathrm{mbsf}$, a relatively sharp shift in paleoflora composition with a marked decrease in Carya spp. suggests possible condensation or an erosive surface (see Sect. 3.1). Above this interval, a significant increase $\left(t\right.$ test: $t$ stat $=13.1 ; t$ critical $=2 ; p$ value $=2.6 \times 10^{-5} ; \alpha$ $=0.05$ ) in Pinus spp., Alnus and mesothermal elements such as Taxodiaceae-Cupressaceae and Platycarya, indicates the development of moderately diverse mixed conifer-broadleaf vegetation, potentially pointing to the recovery phase of the PETM. However, the presence of rare mesothermalmegathermal elements (e.g., palms/cycads, Engelhardia, and Icacinaceae) indicates the persistence of a relatively warm climate.

\subsection{Quantitative paleoclimate analysis}

We applied nearest living relative analysis on the spore and pollen assemblages using both bioclimatic analysis and the Mutual Climate Range (MCR) technique to reconstruct MAT, CMMT and WMMT. However, we only present the estimates from MCR as these data show the clearest trends (Fig. 4). We assume that the ecological and climatic preferences of the fossil spore and pollen assemblages are similar to their extant living relatives. 


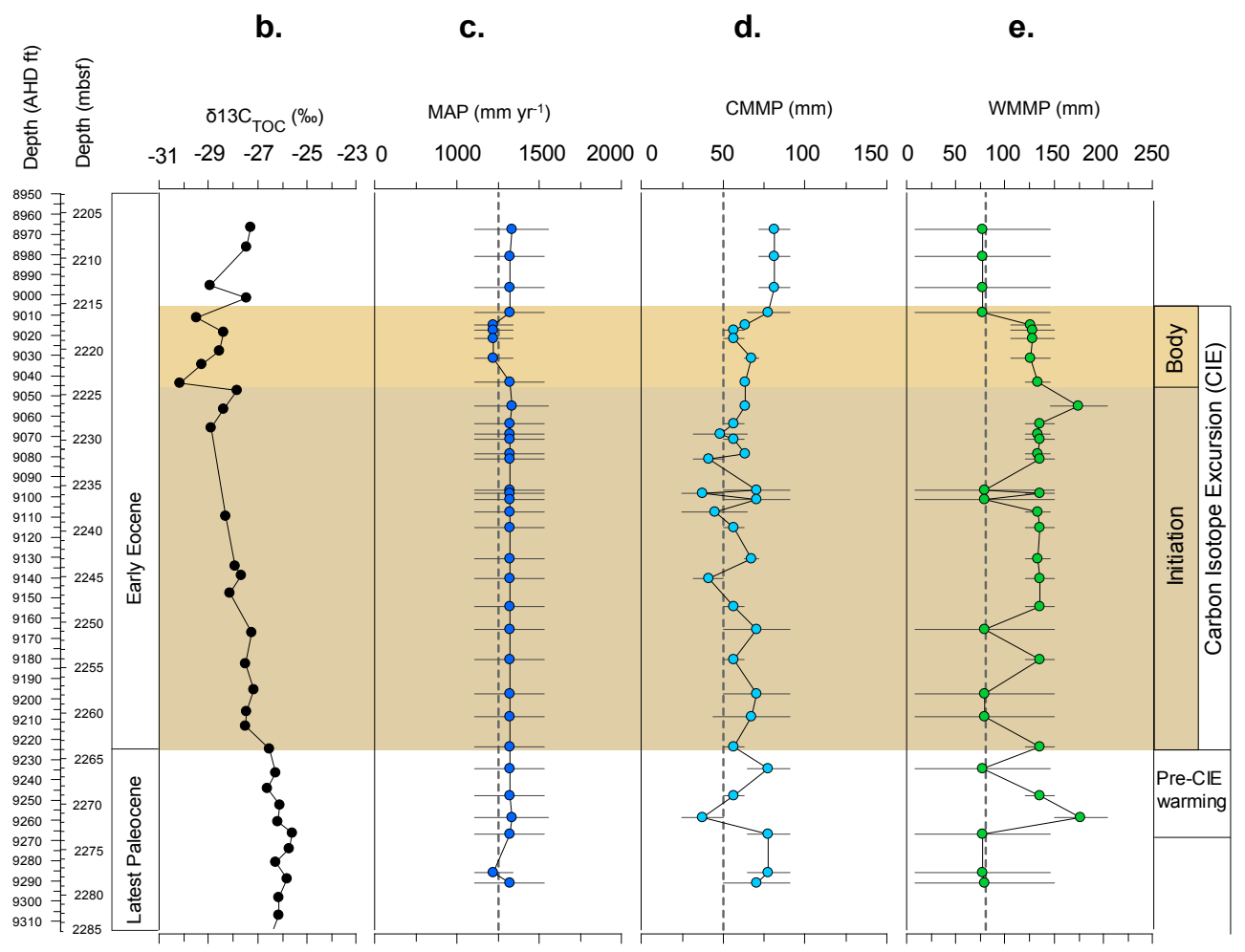

Fig. 5. Record of Paleocene-Eocene precipitation data from well 22/11-N1: (a) depth and age, (b) carbon isotope data $\left(\delta^{13} \mathrm{C}_{\mathrm{TOC}}\right)$, (c) MAP, (d) CMMP, and (e) WMMP. (c-e) Horizontal bars and shaded area represent the minimum and maximum estimate returned from the method.

\subsubsection{Temperature reconstructions}

Our data indicate that the late Paleocene climate was generally warm, with MAT $\sim 15^{\circ} \mathrm{C}, \mathrm{CMMT} \sim 8^{\circ} \mathrm{C}$ and WMMT $\sim 22.5^{\circ} \mathrm{C}$, respectively (Fig. $4 \mathrm{c}-\mathrm{e}$ ). Our data indicate, that for the latest Paleocene, just prior to the CIE initiation, MAT is estimated at $16-17^{\circ} \mathrm{C}$, indicating a $1-2^{\circ} \mathrm{C}$ warming. A $t$ test confirms that this warming prior to the CIE is significant ( $t$ stat $=4.5 ; t$ critical $=3.1 ; p$ value $=0.02 ; \alpha=0.05)$. In addition our estimates of WMMT, which are $\sim 25^{\circ} \mathrm{C}$, also represent a $2{ }^{\circ} \mathrm{C}$ warming prior to the $\mathrm{CIE}(t$ test: $t$ stat $=$ $3.5 ; t$ critical $=2.7 ; p$ value $=0.02 ; \alpha=0.05$ ). Our estimates of CMMT are $\sim 9^{\circ} \mathrm{C}$, indicating no significant change in CMMT prior to the CIE ( $t$ test: $t$ stat $=0.8 ; t$ critical $=2.8$; $p$ value $=0.4 ; \alpha=0.05)$; however, one sample $(2266.7 \mathrm{mbsf})$ provides an estimate of $\sim 11.2^{\circ} \mathrm{C}$ possibly reflecting greater variability leading up to the CIE. Our temperature estimates for MAT and WMMT remain elevated throughout the CIE, while CMMT significantly increases $(t$ test: $t$ stat $=3.9$; $t$ critical $=2.0 ; p$ value $=0.0002 ; \alpha=0.05)$ to an average of $10.2^{\circ} \mathrm{C}$ during the CIE interval. Our data indicate that both CMMT and WMMT recover to pre-PETM values between 2218.1 and $2216.6 \mathrm{mbsf}$.

Comparison of our climate estimates for the PaleoceneEocene boundary with other European records shows a corresponding shift to warmer summers during the CIE as seen regionally in the Cobham lignite of southern England (Collinson et al., 2009) and Vasterival in northwest France (Storme et al., 2012; Garel et al., 2013; Fig. 1), and also in the North American interior (Secord et al., 2010; Kraus et al., 2013; Wing and Currano, 2013). Our estimates of MAT for the latest Paleocene are generally consistent with those estimates from leaf physiognomy from macroflora from the Bighorn Basin, which show an increase from $12.9 \pm 2.4^{\circ} \mathrm{C}$ to over $15 \pm 2.4^{\circ} \mathrm{C}$ (Wing and Harrington, 2002; Wing et al., 2005). Furthermore, the pre-CIE warming we detect in both MAT and WMMT estimates from the North Sea may match with that seen in the Bighorn Basin (Secord et al., 2010; Kraus et al., 2013), supporting warmer annual and in particular warmer summer temperatures immediately prior to the CIE.

For the PETM interval itself, our estimates are generally somewhat lower than those recorded elsewhere, which estimate MAT between 20 and $26^{\circ} \mathrm{C}$ based on oxygen isotopes of biogenic phosphate (Fricke et al., 1998), tooth enamel (Koch et al., 2003; Secord et al., 2010), soil nodules (Bowen et al., 2001); soil-derived bacterial membrane lipids (Weijers et al., 2007), and leaf margin analyses (Wing et al., 2005). This partly reflects the variable geographic locations of the selected records. However, these other records of MAT more closely resemble our WMMT estimates, though leaf physiognomy has been shown to yield cooler estimates 
than NLR-based approaches for the same fossil assemblage (Greenwood and Wing, 1995; Greenwood et al., 2005). The variation between our MAT estimate and those derived from oxygen isotope ratios of carbonate and phosphate components (tooth enamel; biogenic phosphate) could be due to seasonal bias in the oxygen isotope ratio of ingested water, while soil-derived bacterial membrane lipids could be biased towards summer values at high latitudes (Weijers et al., 2007).

\subsubsection{Precipitation reconstructions}

We have also calculated precipitation estimates across the PETM of the North Sea, including MAP, and seasonal precipitation estimates including CMMP and WMMP (Fig. 5). Estimates of MAP are high $\left(>1200 \mathrm{~mm} \mathrm{yr}^{-1}\right)$; although there are large uncertainties in this estimate (Fig. 5c), they are similar to those estimated using leaf physiognomy from macroflora from Wyoming, United States (Wing et al., 2005), and late Paleocene to early Eocene estimates from Ellesmere Island in the Arctic (Greenwood et al., 2010). However, we do not see in our record a significant change in MAP ( $t$ test: $t$ stat $=0.8 ; t$ critical $=2.1 ; p$ value $=0.4 ; \alpha=0.05$ ), suggesting continued high precipitation and increased summer temperatures during the PETM, or insensitivity using our methodology to changes in MAP over the interval. Our estimates, however, are consistent with other evidence for high precipitation and continental runoff during the PETM (Schmitz and Pujalte, 2008; Sluijs et al., 2008).

Despite the relatively large range in precipitation estimates, our seasonal precipitation record using WMMP and CMMP (Fig. 5d-e) does provide additional insights into the climate of PETM interval. In particular, our WMMP estimates (Fig. 5e) show a brief shift to wetter conditions preCIE, which, although uncertainties are large, coincides with the first common appearance of the freshwater algae Pediastrum. Our estimates also show a second more significant shift $(t$ test: $t$ stat $=3.9 ; t$ critical $=2 ; p$ value $=0.0002 ; \alpha$ $=0.05)$ to higher summer precipitation $(\mathrm{WMMP} \sim 140 \mathrm{~mm}$ ) late in the CIE initiation and into the CIE body. This latter shift in WMMP corresponds with an abundance of the freshwater peridinioid dinocyst taxon Bosedinia (Prauss, 2012) indicating enhanced continental runoff and salinity stratification in the central North Sea basin at this time associated with the higher summer precipitation. Our seasonal temperature and precipitation estimates provide the first quantification of warmer and wetter summers prior to the CIE in Europe as previously inferred by charcoal distribution in the Cobham lignite (Collinson et al., 2009) and more recently from $\delta^{15} \mathrm{~N}$ (Storme et al., 2012), $n$-alkane $\delta \mathrm{D}$ isotopes (Garel et al., 2013) from Vasterival, northwest France, and increased terrestrial and freshwater palynomorphs from a nearby core in the North Sea (Kender et al., 2012).

\section{Conclusions}

Our data indicate that there was a significant shift towards a seasonally warmer climate immediately prior to and during the Paleocene-Eocene CIE. This climate shift is reflected in particular by (1) reductions in boreal conifers such as Pinaceae and (2) increase in mesothermal to megathermal taxa including palms/cycads, Engelhardia, and Icacinaceae (Iodes-type). The change in vegetation we report occurs prior to the CIE, being concomitant with the onset of the Apectodinium acme prior to the CIE in well 22/11-N1, representing the earliest sign of anomalous PETM-related environmental change also at other North Sea sites (Sluijs et al., 2007; Kender et al., 2012). Our seasonal temperature and precipitation estimates provide the first quantification of warmer and wetter summers prior to the CIE in Europe, being comparable to those seen in some other records from Europe, i.e., a shift to warmer and wetter summers prior to and during the CIE (Collinson et al., 2009; Storme et al., 2012; Kender et al., 2012; Garel et al., 2013).

Within the CIE, there is significant re-organization of the vegetation with initial increases in epiphytic and climbing ferns (Polypodiaceae and Schizaeaceae), and development of extensive wetlands, followed by abundance of Carya spp., indicative of broadleaf forests. Our precipitation estimates, although having large uncertainties, provide the first direct evidence for seasonally wetter summers briefly prior to the CIE and more persistently during the main CIE itself. These shifts to wetter summers correspond with periods on enhanced continental runoff as expressed by the abundance of freshwater indicators such as the algae Pediastrum and the dinocyst taxon Bosedinia and are consistent with enhanced hydrological cycling prior to and during the PETM interval.

The marked increase in WMMT and WMMP (i.e., summer temperatures and precipitation) puts a new perspective on environmental precursors to the injection of carbon during the PETM. Previous studies found anomalous biotic change and at least regional warming to lead the CIE by thousands of years (Thomas et al., 2002; Sluijs et al., 2007; Secord et al., 2011). This suggested that early warming could have caused destabilization of submarine methane hydrates to cause injection of ${ }^{13} \mathrm{C}$-depleted carbon into the global exogenic carbon pool. Recent experiments with a fully coupled atmosphere-ocean climate general circulation model (GCM) supported this scenario (Lunt et al., 2011). In this model, enhanced seasonal contrasts through Milankovitch forcing (Lourens et al., 2005), combined with a gradually warming late Paleocene to early Eocene, forced a non-linear response in ocean circulation to warm intermediate waters. This mechanism, which explains not only the PETM but also the smaller early Eocene events, should have caused hydrate dissociation if these were present in the early Paleogene (Lunt et al., 2011). Our results show the occurrence of such seasonal extremes just prior to the onset of the CIE and may 
thus represent the smoking gun of a climatologically forced threshold in the carbon cycle that caused the PETM.

\section{Supplementary material related to this article is available online at http://www.clim-past.net/10/759/2014/ cp-10-759-2014-supplement.zip.}

Acknowledgements. We thank Arnold van Dijk for analytical support and Gert-Jan Reichart (Utrecht University) for discussions. D. R. Greenwood's research is supported by the Natural Sciences and Engineering Research Council of Canada (NSERC Discovery Grant \#311934). A. Sluijs thanks the European Research Council under the European Community's Seventh Framework Program for funding through ERC Starting Grant \#259627.

Edited by: Y. Godderis

\section{References}

Australian National Herbarium Specimen Information Register (ANHSIR), available at: http://www.anbg.gov.au/cpbr/program/ hc/hc-ANHSIR.html (last access: August 2011), 2011.

Bowen, G. J., Koch, P. L., Gingerich, P. D., Norris, R. D., Bains, S. and Corfield, R. M.: in: Paleocene-Eocene Stratigraphy and Biotic Change in the Bighorn and Clarks Fork Basins, Wyoming, edited by: Gingerich, P. D. (Univ. of Michigan Papers on Palaeontology 33), 73-88, 2001.

Bowman, M. B. J.: in: Petroleum geology of the North Sea: Basic concepts and recent advances, edited by: Glennie, K. W., 350375, (Oxford: Blackwell Science), 1998.

Bujak, J. P. and Brinkhuis, H.: Global warming and dinocyst changes across the Paleocene/Eocene boundary, in: Aubry, M.P., Lucas, S. G., and Berggren, W. A., Late Paleocene - Early Eocene Climatic and Biotic events in the marine and terrestrial records, Columbia University Press, New York; Chap. 14, 277295 [NSG: 970172], 1998.

Collinson, M. E., Steart, D. C., Harrington, G. J., Hooker, J. J., Scott, A. C., Allen, L. O., Glasspool, I. J., and Gibbons, S. J.: Palynological evidence of vegetation dynamics in response to palaeoenvironmental change across the onset of the PaleoceneEocene Thermal Maximum at Cobham, Southern England, Grana, 48, 38-66, 2009.

Crouch, E. M., Dickens, G. R., Brinkhuis, H., Aubry, M.-P., Hollis, C. J., Rogers, K. M. and Visscher, H.: The Apectodinium acme and terrestrial discharge during the Paleocene-Eocene thermal maximum: new palynological, geochemical and calcareous nannoplankton observations at Tawanui, New Zealand, Palaeogeogr. Palaeoclimatol. Palaeoecol., 194, 387-403, 2003.

Cui, Y., Kump, L. R., Ridgwell, A. J., Charles, A. J., Junium, C. K., Diefendorf, A. F., Freeman, K. H., Urban, N. M., and Harding, I. C.: Slow release of fossil carbon during the Palaeocene-Eocene Thermal Maximum, Nat. Geosci., 4, 481485, doi:10.1038/ngeo1179, 2011.
DeConto, R. M., Galeotti, S., Pangani, M., Tracy, D., Schaefer, K., Tingjun, Z, Pollard, D., and Beerling, D. J.: Past extreme warming events linked to massive carbon release from thawing permafrost, Nature, 484, 87-91, 2012.

Dickens, G. R., O'Neil, J. R., Rea, D. K., and Owen, R. M.: Dissociation of oceanic methane hydrate as a cause of the carbon isotope excursion at the end of the Paleocene, Palaeoceanography 23, 965-971, 1995.

Dickens, G. R., Castillo, M. M., and Walker, J. C. G.: A blast of gas in the latest Paleocene; simulating first order effects of massive dissociation of oceanic methane hydrate, Geology, 25, 259-262, 1997.

Egger, H., Heilmann-Clausen, C., and Schmitz, B.: From shelf to abyss: Record of the Paleocene/Eocene-boundary in the Eastern Alps (Austria), Geol Act., 7, 215-227, doi:10.1344/105.000000266, 2009.

Eldrett, J. S., Greenwood, D. R., Harding, I. C., and Huber, M.: Increased seasonality through the Eocene to Oligocene transition in northern high latitudes, Nature, 459, 969-974, doi:10.1038/nature08069, 2009.

Fang, J., Wang, Z., and Tang, Z. (Eds.): Atlas of Woody Plants in China, Distribution and Climate, Vols. 1 \& 2, Higher Education Press, Beijing, and Springer-Verlag, Berlin, 1-1972, 2011.

Fricke, H. C., Clyde, W. C., O’Neil, J. R., and Gingerich, P. D.: Evidence for rapid climate change in North America during the latest Paleocene thermal maximum: oxygen isotope compositions of biogenic phosphate from the Bighorn Basin (Wyoming), Earth Planet. Sci. Lett., 160, 193-208, 1998.

Galeotti, S., Krishnan, S., Pangani, M., Lanci, L., Gaudio, A., Zachos, J. C., Monechi, S., Morelli, G., and Lourens, L.: Orbital chronology of Early Eocene hyperthermals from the Contessa Road section, central Italy, Earth Planet. Sci. Lett., 290, 192-200, 2010.

Garel, S., Schynder, J., Jacob, J., Dupuis, C., Boussafir, M., Le Milbeau, C., Storme, J-Y., Iakoleva, A. I., Yans, J., Baudin, F., Flehoc, F., and Quesnel, F.: Paleohyrological and paleoenvironmental changes recorded in terrestrial sediments of the PaleoceneEocene boundary (Normandy, France), Palaeogeogr. Palaeocli. Palaeoecol., 376, 184-199, 2013.

Greenwood, D. R. and Wing, S. L.: Eocene continental climates and latitudinal temperature gradients, Geology, 23, 1044-1048, 1995.

Greenwood, D. R., Archibald, S. B., Mathewes, R. W., and Moss, P. T.: Fossil biotas from the Okanagan Highlands, southern British Columbia and northeastern Washington State: climates and ecosystems across an Eocene landscape, Can. J. Earth Sci. 42, 167-185, doi:10.1139/E04-100, 2005.

Greenwood, D. R., Basinger, J. F., and Smith, R. Y.: How wet was the Arctic Eocene rainforest? Estimates of precipitation from Paleogene Arctic macrofloras, Geology, 38, 15-18, doi:10.1130/G30218.1, 2010.

Grimm, G. W. and Denk, T.: Reliability and resolution of the coexistence approach ? A revalidation using modern-day data, Rev. Palaeobot. Palynol., 172, 33-47, 2012.

Håland, H. J., Furnes, H., and Martinsen, O. J.: Paleogene tuffaceous intervals, Grane Field (Block 25/11), Norwegian North Sea: their depositional, petrographical, geochemical character and regional implications, Mar. Petrol. Geol., 17, 101-118, 2000. 
Harding, I. C., Charles, A. J., Marshall, J. E. A., Pälike, H., Roberts, A. P., Wilson, P. A., Jarvis, E., Thorne, R., Morris, E., Moremon, R., Pearce, R. B., and Akbari, S.: Sea-level and salinity fluctuations during the Paleocene-Eocene thermal maximum in Arctic Spitsbergen, Earth Planet. Sci. Lett., 258, 581-592, 2011.

Harrington, G. J.: Comparisons between Paleocene-Eocene paratropical swamp and marginal marine pollen floras from Alabama and Mississippi, USA, Palaeontology, 51, 611-622, 2008.

Hijmans, R. J., Cameron, S. E., Parra, J. L., Jones, P. G., and Jarvis, A.: Very high resolution interpolated climate surfaces for global land areas, Int. J. Climatol., 25, 1965-1978, 2005.

Hijmans, R. J., Cameron, S. E., and Parra, J. L.: WorldCLIM global climate data, http://www.worldclim.org/ (last access: December 2012), 2012.

Hooghiemstra, H.: Palynological records from northwest African marine sediments: a general outline of the interpretation of the pollen signal, Philos. Trans. Roy. Soc. London B, 318, 431-449, 1998.

Kender, S., Stephenson, M. H., Riding, J. B., Leng, M. J., Knox, R. W. O. B, Peck, V. L., Kendrick, C. P., Ellis, M. A., Vane, C. H., and Jamieson, R.: Marine and terrestrial environmental changes in NW Europe preceding the carbon release at the PaleoceneEocene transition, Earth Planet. Sc. Lett., 353-354, 108-120, 2012.

Koch, P. L., Cylde, W. C., Hepple, R. P., Fogel, M. L., Wing, S. L., and Zachos, J. C.: in: Causes and Consequences of Globally Warm Climates in the Early Palaeogene, edited by: Wing, S. L., Gingerich, P. D., Schmitz, B., and Thomas, E. (Geological Society of America Special Paper 369), 49-64, 2003.

Kraus, M. J., McInerney, F. A., Wing, S. L., Secord, R., Baczynski, A. A., and Bloch, J. I.: Paleohydrologic response to continental warming during the Paleocene-Eocene thermal maximum, Bighorn Basin, Wyoming, Palaeogeogr. Palaeocli. Palaeoecol., 370, 196-208, 2013.

Kurtz, A. C., Kump, L. R., Arthur, M. A., Zachos, J. C., and Paytan, A.: Early Cenozoic decoupling of the global carbon and sulphur cycles, Palaeoceanography, 18, 1090-1104, 2003.

Lourens, L. J., Sluijs, A. P., Kroon, D., Zachos, J. C., Thomas, E., Röhl, U., Bowles, J., and Raffi, I.: Astronomical pacing of late Palaeocene to early Eocene global warming events, Nature, 435, 1083-1087, 2005.

Lowenstein, T. K. and Demicco, R. V.: Elevated Eocene atmospheric $\mathrm{CO}_{2}$ and its subsequent decline, Science, 313, 1928 pp., doi:10.1126/science.1129555, 2006.

Lunt, D. J., Ridgwell, A., Sluijs, A., Zachos, J. C., Hunter, S., and Haywood, A.: A model for orbital pacing of methane hydrate destabilization during the Palaeogene, Nat. Geosci., 4, 775-778, 2011.

Maclennan, J. and Jones, S. M.: Regional uplift, gas hydrate dissociation and the origins of the Paleocene-Eocene Thermal Maximum, Earth Planet. Sci. Lett., 245, 65-80, 2006.

McInerney, F. A. and Wing, S. L.: The Paleocene-Eocene thermal maximum: A perturbation of the carbon cycle, climate, and biosphere with implications for the future, Annu. Rev. Earth Planet. Sci. Lett., 39, 489-516, 2011.

Mosbrugger, V. and Utescher, T.: The coexistence approach - a method for quantitative reconstructions of Tertiary terrestrial palaeoclimate data using plant fossils, Palaeogeogr. Palaeocli. Palaeoecol., 134, 61-86, 1997.
Mudge, D. C. and Jones, S. M.: Paleocene uplift and subsidence events in the Scotland-Shetland and North Sea region and their relationship to the Iceland plume, J. Geol. Soc., London, 161, 381-386, 2004.

Natural Resources Canada: Climatic Range map (1971-2000 scenario)/climatic profile: Canadian Forest Service, Sault Ste. Marie, available at: http://planthardiness.gc.ca/index.pl?lang= en\&m=13\&p=1 (last access: May, 2012), 2012.

Panchuk, K., Ridgwell, A., and Kump, L. R.: Sedimentary response to Paleocene-Eocene Thermal Maximum carbon release: A model-data comparison, Geology, 36, 315-318, 2008.

Piper, D. J. W. and Deptuck, M.: Fine-graomed turbidites of the Amazon Fan: facies characterization and interpretation, in: Proceedings of the ODP. Sci Res., 155, edited by: Flood, R. D., Piper, D. J. W., Klaus, A., and Peterson, I., Ocean Drilling Program, College Station, Texas, 79-108, 1997

Prauss, M. L.: The Cenomanian/Turonian Boundary event (CTBE) at Tarfaya, Morocco: Palaeoecological aspects as reflected by marine palynology, Cretaceous Res., 34, 233-256, 2012.

Primez, C., Prather, B. E., Millarino, G., O'Hayer, W. W., Droxler, A. W., and Winkler, C. D.: Chronostratigraphy of the BrazosTrinity depositional system, western Gulf of Mexico: Implications for deepwater depositional models, in Application of the Principles of Seismic Geomorphology to Continental-Slope and Base-of-Slope Systems: Case Studies from Seafloor and NearSeafloor Analogues, SEPM Special Publication, 99, 111-143, doi:10.2110/pec.12.99, 2012.

Pross, J., Contreras, L., Bijl, P. K., Greenwood, D. R., Bohaty, S. M., Schouten, S., Bendle, J. A., Röhl, U., Tauxe, L., Raine, J. I., Huck, C. E., van de Flierdt, T., Jamieson, S. S. R., Stickley, C. E., van de Schootbrugge, B., Escutia, C., Brinkhuis, H., and IODP Expedition 318 Scientists: Persistent near-tropical warmth on the Antarctic continent during the early Eocene epoch, Nature, 488, 73-77, doi:10.1038/nature11300, 2012

Royer, D. L., Osborne, C. P., and Beerling, D. J.: High $\mathrm{CO}_{2}$ increases the freezing sensitivity of plants: Implications for palaeoclimatic reconstructions from fossil floras, Geology, 30, 963966, 2002.

Schmitz, B. and Pujalte, V.: Abrupt increase in seasonal extreme precipitation at the Paleocene-Eocene boundary, Geology, 35, 215-218, 2007.

Schmitz, B., Peucker-Ehrenbrink, B., Heilmann-Clausen, C., Åberg, G., Asaro, F., and Lee, C-T.: Basaltic explosive volcanism, but no comet impact, at the Paleocene-Eocene boundary: high-resolution chemical and isotopic records from Egypt, Spain and Denmark, Earth Planet. Sc. Lett., 225, 1-17, 2004.

Schoon, P. L., Heilmann-Clausen, C., Schultz, B. P., Sluijs, A., Sinninghe Damsté, J. S., and Schouten, S.: Recognition of Early Eocene global carbon isotope excursions using lipids of marine Thaumarchaeota, Earth Planet. Sc. Lett., 373, 160-168, 2013.

Schroder, T. A.: Palynological zonation for the Paleocene of the North Sea, J. Micropalaeontol., 11, 113-126, 1992.

Schuettpelz, E. and Pryer, K. M.: Evidence for a Cenozoic radiation of ferns in an angiosperm-dominated canopy, Proc. Natl. Acad. Sci., 106, doi:10.1073/pnas.0811136106, 2009.

Secord, R., Gingerich, P. D., Lohmann, K. C., and MacLeod, K. G.: Continental warming preceding the Palaeocene-Eocene thermal maximum, Nature, 467, 955-958, 2010. 
Sluijs, A. and Brinkhuis, H.: A dynamic climate and ecosystem state during the Paleocene-Eocene Thermal Maximum: inferences from dinoflagellate cyst assemblages on the New Jersey Shelf, Biogeosciences, 6, 1755-1781, 2009,

http://www.biogeosciences.net/6/1755/2009/.

Sluijs, A. and Dickens, G. R.: Assessing offsets between the $\delta^{13} \mathrm{C}$ of sedimentary components and the global exogenic carbon pool across early Paleogene carbon cycle perturbations, Global Biogeochem. Cy., 26, GB4005, doi:10.1029/2011GB004224, 2012.

Sluijs, A., Brinkhuis, H., Schouten, S., Boharty, S. M., John, C. M., Zachos, J. C., Reichart, G.-J., Sinninghe Damsté, J. S., Crouch, E. M., and Dickens, G. R.: Environmental precursors to rapid light carbon injection at the Palaeocene/Eocene boundary, Nature, 450, 1218-1221, 2007.

Sluijs, A., Brinkhuis, H., Crouch, E. M., John, C. M., Handley, L., Munsterman, D., Boharty, S. M., Zachos, J. C., Reichart, G.-J., Schouten, S., Pancost, R. D., Sinninghe Damsté, J. S., Welters, N. L. D., Lotter, A. F., and Dickens, G. R.: Eustatic variations during the Paleocene-Eocene greenhouse world, Palaeoceanography 23, PA4216, doi:10.1029/2008PA001615, 2008.

Smith, R. Y., Greenwood, D. R., and Basinger, J. F.: Coupling of globally warm temperatures and high levels of $\mathrm{pCO}_{2}$ during the Early Eocene Climatic Optimum: evidence from the Falkland flora of the Okanagan Highlands, Canada, Palaeogeogr. Palaeoclimatol. Palaeoecol., 293, 120 131, doi:10.1016/j.palaeo.2010.05.006, 2010.

Song, Z.-C., Wang, W.-M., and Huang, F.: Fossil Pollen Records of Extant Angiosperms in China, The Botanical Rev., 70, 425-458, 2004.

Storme J.-Y., Dupuis, C., Schnyder, J., Quesnel, F., Garel, S., Iakovleva, A.I., Iacumin, P., Di Matteo, A., Sebilo, M., and Yans, J.: Cycles of humid-dry climate conditions around the P/E boundary: new stable isotope data from terrestrial organic matter in Vasterival section (NW France), Terra Nova, 24, 114-122, 2012.

Svensen H., Planke, S., and Corfu, F.: Zircon dating ties NE Atlantic sill emplacement to initial Eocene global warming, J. Geol. Soc. London, 167, 433-436, 2010.
Thomas, D. J., Zachos, J. C., Bralower, T. J., Thomas, E., and Boharty, S.: Warming the fuel for the fire: Evidence for the thermal dissociation of methane hydrate during the Paleocene-Eocene thermal maximum, Geology, 30, 1067-1070, 2002.

Thompson, R. S., Anderson, K. H., Pelltier, R. T., Strickland, L. E., Bartlein, P. J., and Shafer, S. L. Quantitative estimation of climatic parameters from vegetation data in North America by the mutual climatic range technique, Quaternary Sci. Rev., 51, 18-39, 2012.

Underhill, J. R.: Controls on the genesis and prospectivity of Paleogene palaeogeomorphic traps, East Shetland Platform, UK North Sea, Mar. Petrol. Geol., 18, 259-281, 2001.

Weijers, J. W. H., Schouten, S., Sluijs, A., Brinkhuis, A., and Sinninghe Damsté, J. S.: Warm arctic continents during the Palaeocene-Eocene thermal maximum, Earth Planet. Sci. Lett., 261, 230-238, 2007.

White, N. and Lovell, B.: Measuring the pulse of a plume with the sedimentary record, Nature, 387, 888-891, 1997.

Wing, S. L. and Currano, E. D.: Plant response to a global greenhouse event 56 million years ago, Am. J. Botany, 100, 12341254, 2013.

Wing, S. L. and Harrington, G. J.: Floral response to rapid warming in the earliest Eocene and implications for concurrent faunal change, Palaeobiology, 27, 539-563, 2001.

Wing, S. L., Harrington, G. J., Smith, F. A., Bloch, J. I., Boyer, D. M., and Freeman, K. H.: Transient floral change and rapid global warming at the Paleocene-Eocene boundary, Science, 310, 993 996, 2005.

$\mathrm{Xu}, \mathrm{T}$. and Hutchinson, M.: New developments and applications in the ANUCLIM spatial climatic and bioclimatic modelling package, Environ. Modell. Softw., 40, 267-279, doi:10.1016/j.envsoft.2012.10.003, 2013.

Zachos, J. C., Röhl, U., Schellenberg, S. A., Sluijs, A., Hodell, D. A., Kelly, D. C., Thomas, E., Nicolo, M., Raffi, I., Lourens, L. J., McCarren, H., and Kroon, D.: Rapid Acidification of the Ocean during the Paleocene-Eocene Thermal Maximum, Science, 308, 1611-1615, 2005. 